\title{
STIPA GLAREOSA (POACEAE) IN THE REPUBLIC OF BURYATIA (RUSSIA)
}

\author{
Polina D. Gudkova, Marcin Nobis ${ }^{1}$, Aleksandr L. Ebel, Daba G. Chimitov \\ \& Alla V. Verkhozina
}

\begin{abstract}
Stipa glareosa P. A. Smirn. (sect. Smirnovia Tzvel.) is reported for the first time from the Republic of Buryatia (Russia). Its stations are located at the northern limit of its general distribution range. The taxonomy, distribution and habitat preferences of the species are given, along with its population size at each new locality.
\end{abstract}

Key words: distribution, habitat, limit range, new records, Stipa

Polina D. Gudkova, Laboratory of Biodiversity and Ecology, Institute of Biology, Tomsk State University, 36 Lenin Prospect, Tomsk, 634050, Russia, and Department of Botany, Altay State University, 61 Lenin Prospekt, Barnaul, 656049, Russia Marcin Nobis, Laboratory of Biodiversity and Ecology, Institute of Biology, Tomsk State University, 36 Lenin Prospect, Tomsk, 634050, Russia, and Department of Plant Taxonomy, Phytogeography and Herbarium, Institute of Botany, Jagiellonian University, Kopernika 27, 31-501 Kraków,Poland; e-mail:m.nobis@uj.edu.pl

Aleksandr L. Ebel, Laboratory of Biodiversity and Ecology, Institute of Biology, Tomsk State University, 36 Lenin Prospect, Tomsk, 634050, Russia

Daba G. Chimitov, Ecology and Life Safety Department, Ecology and the Humanities Faculty, East Siberia State University of Technology and Management, Klyuchevskaya 40V, Ulan-Ude, 670013, Russia

Alla V. Verkhozina, Siberian Institute of Plant Physiology \& Biochemistry of Siberian Branch of Russian Academy of Sciences, Irkutsk-33 P.O. Box 317, 664033, Russia

The Republic of Buryatia is located in two southeastern Siberian provinces: Transbaikal and Cisbaikal (Gvozdetsky \& Mikhailov 1978). The majority of its area is covered by forest vegetation. Steppe and forest-steppe vegetation occur mainly in the southern part of the region. In the western Transbaikal province (Transbaikal subregion), steppe areas are distributed like islands within broad valleys of tectonic origin, bordered by mountain ranges (Reshchikov 1961). An analysis of the isolated steppe associations as well as information on species composition outside of their main distribution range can be used to reconstruct the history of the vegetation (Banzragch et al. 1975). From this point of view, the localities of Stipa glareosa P. A. Smirn., which has been found in the western Transbaikal, are of particular interest. Stipa glareosa was not previously listed from the territory of Buryatia (Lomonosova 1990;

\footnotetext{
1 Corresponding author
}

Badmaeva 2001). The species was first found in the vicinity of Inzagatui village in 2009 (Namzalov et al. 2011) but it was erroneously determined as S. klemenzii Roshev. (specimen revised by P. Gudkova). Stipa glareosa clearly differs from that species by having a pubescent (vs. glabrous) lower part of the awn, an anthecium with a well developed ring of hairs at the apex (vs. anthecium with a glabrous apex), and a dorsal line of hairs at the anthecium, ending in its upper half (vs. dorsal line of hairs at the anthecium, ending in the lower half) (Pazij 1968; Tzvelev 1968, 1976; Gonzalo et al. 2011; Nobis 2011, 2014).

Stipa glareosa belongs to section Smirnovia Tzvel. The species is morphologically close to $S$. caucasica Schmalh., but it clearly differs by having longer ligules of vegetative leaves, the scabrousness of leaves, glume length, callus length and shape, the length of hairs in the lower part of the awn, as well as its more northeastern general distribution pattern and different habitat preferences. 


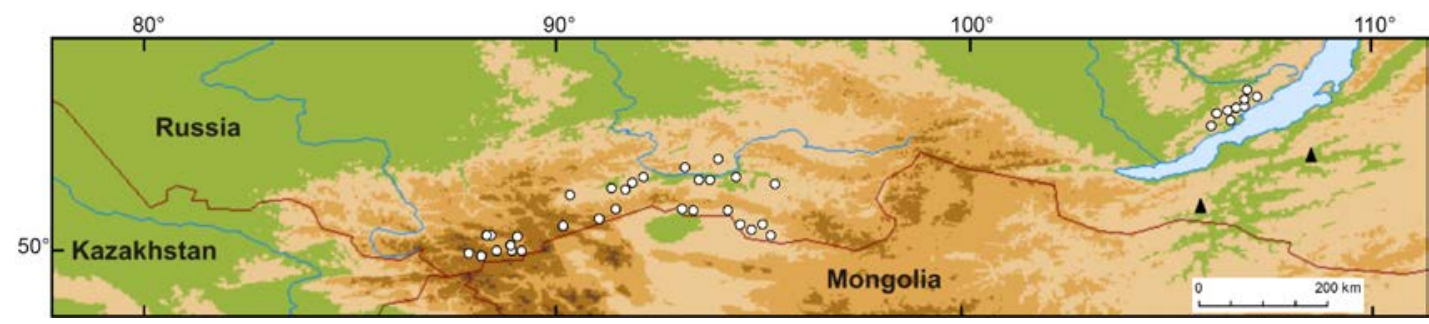

Fig. 1. Distribution map of Stipa glareosa P. A. Smirn. in southern Siberia. $\bigcirc-$ locality known from literature (Lomonosova 1990), $\boldsymbol{\Delta}$ - new locality in Buryatia.

Despite these differences, there are still conflicting opinions about the taxonomic position of Stipa glareosa; some authors treat it as a separate species (Smirnov 1929a, b; Roshevitz 1934; Tzvelev 1968, 2012; Pazij 1968; Lomonosova 1990; Gudkova et al. 2013; Nobis 2013) while others, treat it as a subspecies of S. caucasica (Tzvelev 1974, 1976; Freitag 1985; Wu \& Phillips 2006; Gonzalo et al. 2011). A taxonomic revision of the $S$. caucasica group in its entire distribution range, including the use of molecular methods, is needed.

Stipa glareosa has a Central Asian type of distribution. It occurs in southern Russia (Altai, Tyva and Irkutsk regions), Mongolia, China, Kazakhstan, Kyrgyzstan, Tajikistan, Afghanistan, Pakistan and India (Smirnov 1929a, 1929b; Roshevitz 1934; Tzvelev 1976; Freitag 1985; Wu \& Phillips 2006; Gonzalo et al. 2011; Gudkova et al. 2013). The species is one of the main components of the Central Asian desert steppes of the Stipetea glareosogobicae (Hilbig 2000). It is considered a tertiary steppe relict in southern Siberia (Peshkova 1972).

New locations of Stipa glareosa (Fig. 1) were found on three hills in the Maliy Khamar-Daban foothills (Inzagatui creek valley), on southwestern and southeastern slopes facing the basin, in the Borgoiskoi steppe, as well as on the slopes of a hill on the left bank of the Kurba River in the UlanBurgasi foothills (Fig. 2).

\section{Stipa glareosa P. A. Smirn.}

Byull. Moskovsk. Obshch. Isp. Prir. Otd. Biol. 38(1-2): 12. 1929.

Type Citation: Gobi. Steppum glareosum in depressione lac. Orok-nor, 7.IX.1924. lg. N. Pavlov 169.
TyPe (original label): [label 1] Plantae Mongoliae, Stipa caucasica Schmalh., Gobi, shchebnistaya, galechnaya step v kotlovine oz. Orok-nor. 7-IX-24. N. 169, leg. et det. N. Pavlov; [label 2] Stipa glareosa P. Smirn. sp. n., typus speciei 1929.III. det. P. Smirnov (HOLOTYPE MW!; ISOTYPES LE!).

$\equiv$ Stipa caucasica subsp. glareosa (P. A. Smirn.) Tzvel.

Plant perennial, densely tufted; culms 10$25(-35) \mathrm{cm}, 2-3$ noded, somewhat pubescent under nodes. Leaves of vegetative shoots: sheaths usually somewhat pubescent, less often with spinules; ligules short, up to $0.7 \mathrm{~mm}$ long, densely covered with long hairs; blades glaucous, usually shorter than stem, convolute $(0.3-) 0.4-0.5(-0.6) \mathrm{mm}$ in diameter, abaxial surface along the entire length or only on the lower part covered with spinules or rarely glabrous, smooth, adaxial surface covered with short hairs up to $0.25 \mathrm{~mm}$ long. Cauline leaves: sheaths shorter than internodes, ciliate at margins, lower sheaths somewhat pubescent, rarely almost glabrous, upper sheaths up to $12 \mathrm{~cm}$ long, inflated or not, glabrous or slightly scabrous, leaves scabrous to glabrous. Glumes $20-30 \mathrm{~mm}$ long. Anthecium 9-10 mm long with line of hairs usually terminating below top, ring of hairs at base of awn well developed. Callus 1.7-2.8 mm long, shortly pilose. Awn 5-7 cm long, unigeniculate, pilose along its whole length, lower part (column) $1.2-1.5 \mathrm{~cm}$ long, upper part (seta) $4-6 \mathrm{~cm}$ long. Longest hairs in middle part of column $1.5-2 \mathrm{~mm}$, hairs on seta 4-4.5 $\mathrm{mm}$ long.

SPeCimens EXAmined: RUSSIA. RePUBlic of BuRYATIA: Dzhidinsky district, surroundings of Inzagatui village ( $5 \mathrm{~km}$ to $\mathrm{NW}$ ), $50^{\circ} 53^{\prime} 02^{\prime \prime} \mathrm{N}, 105^{\circ} 42^{\prime} 05^{\prime \prime} \mathrm{E}$, alt. 1010 m, 31 July 2014, P.D. Gudkova, M. Nobis, 
A.L. Ebel, A.V. Verkhozina (TK, KRA, IRK); Zaigraivskii district, surroundings of Unegetei village $(9 \mathrm{~km}$ to NE), Belaya Gora, $52^{\circ} 10^{\prime} 42^{\prime \prime} \mathrm{N}, 108^{\circ} 36^{\prime} 07^{\prime \prime} \mathrm{E}$, alt. 691 m, 28 Aug. 2014, D.G. Chimitov, D.V. Sandanov (UUDE).

Habitat. At the site near Inzagatui village, steppe grassland with Stipa glareosa occur at 980-1100 $\mathrm{m}$ a.s.1. on gravelly insolated slopes (SSW-S-SSE exposure) with a 5-25\% gradient. The general projective coverage of plants is $50-65 \%$. These communities are quite rich in plant species; $27-43$ taxa were noted on the examined plots $(5 \mathrm{~m} \times 5 \mathrm{~m})$. Together with $S$. glareosa, which was most abundant in these patches, Thymus serpyllum L. s.1., Artemisia commutata Bess., Koeleria macrantha (Ledeb.) Schult. and Orostachys spinosa (L.) C. A. Mey. were also noted as numerous. Among the permanent species (registered in all five examined patches with $S$. glareosa) were Alyssum obovatum (C. A. Mey.) Turcz., Bupleurum bicaule Helm, Carex pediformis C. A. Mey., Chamaerhodos altaica (Laxm.) Bunge, Festuca pseudovina Hack. ex Wiesb., F. sibirica Hack. ex Boiss., Gypsophyla patrinii Ser. and Silene jenisseensis Willd. Down the hill there is a steppe area with Stipa grandis P. Smirn., S. baicalensis Roshev. and S. krylovii Roshev. as the dominant plants.

The locality of Stipa glareosa near Unegetei village is on the south slope of Belaya Gora (Eng.: White Hill). The species is observed in steppe grassland on the southern slope of the hill. Together with $S$. glareosa, the following plants were the most abundant: Achnatherum sibiricum (L.) Keng ex Tzvel., Selaginella sanguinolenta (L.) Spring, Thymus serpyllym, Artemisia frigida Willd. and Chamaerhodos altaica.
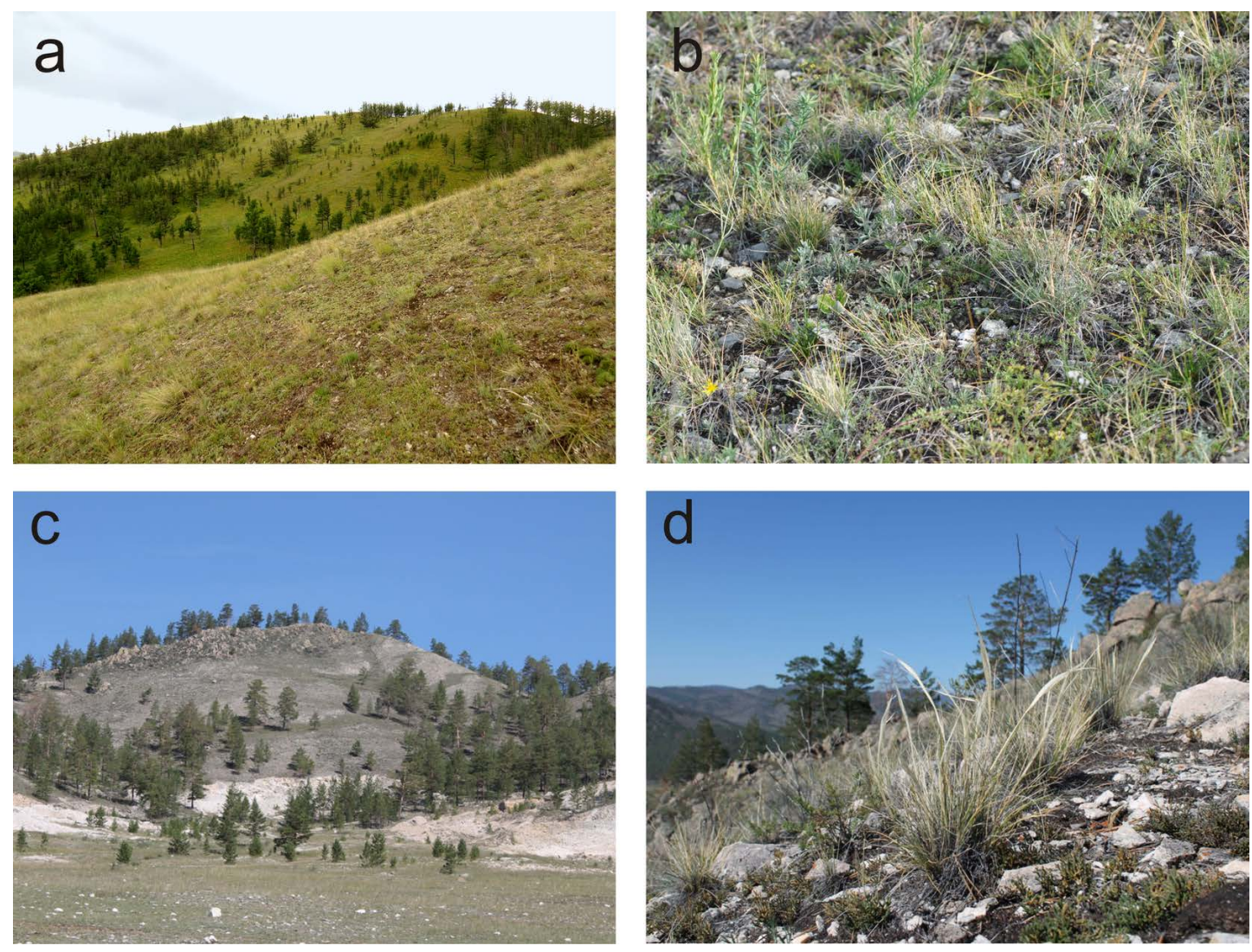

Fig. 2. Habitat of Stipa glareosa P. A. Smirn. near Inzagatui village (a \& b) and near Unegetei village (c \& d). 
Below we present selected phytosociological relevés taken in the patches with domination of Stipa glareosa. The nomenclature of vascular plants listed in this section was adopted from Cherepanov (1995).

1. Steppe grassland on hillside, $50^{\circ} 88^{\prime} 12^{\prime \prime} \mathrm{N}$, $105^{\circ} 69^{\prime} 66^{\prime \prime} \mathrm{E}, 31 \mathrm{July} 2014$, area $20 \mathrm{~m}^{2}$, alt. $1090 \mathrm{~m}$ a.s.1., exposure S-SE, slope $20^{\circ}$, projective cover of herbaceous plants $50 \%$. List of species: Thymus serpyllum s.1. 2-3, Carex pediformis 2, Festuca sibirica 2, Gypsophila patrinii 2, Orostachys spinosa 2, Arctogeron gramineum 1, Artemisia commutata 1, Bupleurum bicaule 1, Festuca pseudovina 1, Filifolium sibiricum 1, Koeleria macrantha 1, Poa botryoides 1, Stemmacantha uniflora 1, Stipa baicalensis 1, S. glareosa 1, Youngia tenuifolia 1 , Aconogonon angustifolium + , Allium tenuissimum +, Alyssum obovatum +, Androsace incana +, Aster alpinus + , Caragana pygmaea + , Chamaerhodos altaica + , Chrysanthemum zawadzkii + , Cymbaria dahurica + , Delphinium grandiflorum + , Eremogone meyeri + , Heteropappus altaicus + , Iris potaninii + , Oxytropis coerulea,+ O. triphylla + , Patrinia rupestris + , Phlojodicarpus sibiricus + , Potentila sericea + , Ptilotrichum tenuifolium + , Pulsatilla tenuiloba + , Saussurea salicifolia +, Scabiosa comosa +, Silene jeniseensis +, Stellaria cherleriae + , Stipa krylovii + , Veronica incana + , Vicia nervata + .

2. Steppe grassland on hillside; $50^{\circ} 53^{\prime} 02^{\prime \prime} \mathrm{N}$, $105^{\circ} 42^{\prime} 05^{\prime \prime} \mathrm{E}, 31 \mathrm{July} 2014$, area $25 \mathrm{~m}^{2}$, alt. $1010 \mathrm{~m}$ a.s.l., exposure SSW, slope $25^{\circ}$, projective cover of herbaceous plants $65 \%$, projective cover of mosses $1 \%$. List of species: Thymus serpyllum s.1. 3, Gypsophila patrinii 2, Koeleria macrantha 2, Stipa glareosa 2, Artemisia commutata 1-2, Leontopodium leontopodioides 1-2, Achnatherum sibiricum 1, Allium sp. 1, Androsace incana 1, Bupleurum bicaule 1, Chrysanthemum zawadzkii 1, Festuca pseudovina 1, F. sibirica 1, Gentiana squarrosa 1, Orostachys spinosa 1, Oxytropis sp. 1, Potentilla acaulis 1, Silene jeniseensis 1, Youngia tenuifolia 1, Alyssum obovatum +, Amblynotus rupestris + , Carex pediformis + , Chamaerhodos altaica + , Delphinium grandiflorum + , Oxytropis triphylla + , Sanguisorba officinalis +, Stipa baicalensis +, S. krylovii +, Thalictrum squarrosum + , Veronica incana + .

ACKNOWLEDGEMENTS. We are grateful to the anonymous reviewer for helpful remarks on the manuscript. The research of P. Gudkova was supported by the Russian Foundation for Basic Research, grant no. 14-04-31962 mol_a, and the research of M. Nobis was financially supported by the National Science Centre, Poland, on the basis of decision no. DEC-2013/09/B/NZ8/03287.

\section{REFERENCES}

Badmaeva N. K. 2001. Rod Stipa L. - Kovyl'. In: O. A. AnenKHONOV (ed.), Opredelitel' rastenij Buryatii, pp. 142-143. Respublikanskaya Tipigrafiya, Ulan-Ude.

Banzragch D., Karamysheva Z. V., Munh-Bayr S. \& CeGMID C. 1975. Novye nahodki peristyh kovylej na territorii stepnoj chasti MNR. Bot. Zhurn. 60(5): 679-687.

Cherepanov S. K. 1995. Vascular plants of Russia and adjacent states (the former USSR). Cambridge University Press, Cambridge.

Freitag H. 1985. The genus Stipa (Gramineae) in southwest and south Asia. Notes R. Bot. Gard. Edinb. 42: 355-489.

Gonzalo R., Aedo C. \& García M. Á. 2011. Taxonomic revision of Stipa section Smirnovia and section Subsmirnovia (Poaceae). Bot. J. Linn. Soc. 167: 394-448.

Gudkova P. D, Ebel A. L., Nobis M. \& Verkhozina A. V. 2013. Stipa glareosa P.A. Smirn. (Poaceae) in the Cisbaical Region. In: V. G. LikHACHEVA (ed.), Integratsya botanicheskikh issledovanii i obrazovaniya: traditsii i perspektivy. Trudy Mezhdunarodnoi nauchno-prakticheskoi konferentsii, posvyaschennoi 125-letiyu Kafedry Botaniki (Tomsk, 12-15 noyabrya 2013), pp. 38-41. Izdatel'stvo Tomskogo Universiteta, Tomsk.

Gvozdetsky N. A. \& Mikhailov N. I. 1978. Fizicheskaya geografiya SSSR. Aziatskaya chast'. Mysl', Moskva.

HILbIG W. 2000. Kommentierte Übersicht über die Pflanzengesellschaften und ihre höheren Syntaxa in der Mongolai. Feddes Repert. 111(1-2): 75-120.

Lomonosova M. N. 1990. Stipa L. - Kovyl'. In: L. I. MaLYShev \& G. A. Peshrova (eds), Flora Sibiriae, Poaceae (Graminae). 2: 222-230. Nauka, Novosibirsk.

Namzalov B. B., Alymbaeva J. B., Bal'zhinova S. Ch. \& Namzalov M. B. 2011. New record of Stipa klemenzii Roshev. in the west Transbaical region. In: A. I. SHMAKov (ed.), Problemy botaniki Yuzhnoj Sibiri i Mongolii: Sbornik nauchnyh statej po materialam X Mezhdunarodnoj nauchno-prakticheskoj konferentzii (24-27 October 2011), pp. 96-102. Artika, Barnaul.

NoBIS M. 2011. Remarks on the taxonomy and nomenclature of the Stipa tianschanica complex (Poaceae), on the base of a new record for the flora of Tajikistan (central Asia). Nord. J. Bot. 29: 194-199.

NobIS M. 2013. Taxonomic revision of the Stipa lipskyi group (Poaceae: Stipa section Smirnovia) in the Pamir Alai and Tian-Shan Mountains. Plant Syst. Evol. 299: 1307-1354.

Nobis M. 2014. Taxonomic revision of the Central Asian Stipa tianschanica complex (Poaceae) with particular reference 
to the epidermal micromorphology of the lemma. Folia Geobot. 49: 283-308.

PaziJ V. K. 1968. Stipa L. In: S. S. Kovalevskaya (ed.), Conspectus florae Asiae Mediae. 1: 64-82 \& 200-201. Academia Scientiarum UzSSR, Taschkent.

Peshrova G. A. 1972. Tretichnye relikty v stepnoi flore Baikalskoi Sibiri. Nauchnye chteniya pamyati M. G. Popova 12-13: 25-28.

ReshChikov M. A. 1961. Stepi Zapadnogo Zabaikalya. Trudy Vost.-Sibirsk. Fil., Ser. Biol. 34: 3-174.

Roshevitz R. Yu. 1934. Stipa L. In: V. L. Komarov (ed.), Flora URSS. 2: 79-112. Academia Scientiarum URSS, Leningrad.

Smirnov P. A. 1929a. Stipa glareosa P. Smirn. sp. nova hoc loco. Byull. Moskovsk. Obshch. Isp. Prir. Otd. Biol. 38(1-2): 12-13.

Smirnov P. A. 1929b. Neue Stipen. Repert. Spec. Nov. Regni Veg. 26: 264-271.
Tzvelev N. N. 1968. Gramineae. In: V. I. Grubov (ed.), Plantae Asiae Centralis (secus materies Instituti Botanici nomine V. L. Komarovii). 4: 1-243 \& 12 maps. Nauka, Leningrad.

Tzvelev N. N. 1974. Notulae de tribu Stipae Dum. (fam. Poaceae) in URSS. Novosti Sist. Vyssh. Rast. 11: 4-21 (in Russian).

TzVelev N. N. 1976. Zlaki SSSR. Nauka, Leningrad.

Tzvelev N. N. 2012. Notes on the tribe Stipeae Dumort. (Poaceae). Novosti Sist. Vyssh. Rast. 43: 20-29 (in Russian with English summary).

Wu Z. L. \& Phillips S. M. 2006. Tribe Stipeae. In: Z. Y. Wu, P. H. Raven \& D. Y. Hong, (eds.), Flora of China (Poaceae). 22: 188-212. Science Press, Beijing and Missouri Botanical Garden Press, St. Louis.

Received 21 September 2014 